\title{
COMPARATIVE STUDY ON THE EFFECT OF DIFFERENT FLOOD IRRIGATION METHODS AND MOISTURE REGIMES ON FRUITFUL "ANNA" APPLE TREES
}

\author{
M. A. Fathi ${ }^{(1)}$, S.M. Hussien ${ }^{(1)}$, D. R. Darwesh ${ }^{(1)^{\star}}$ and T. A. Eid ${ }^{(2)}$ \\ (1) Horticulture Research Institute, Agriculture Research Center, Giza, Egypt \\ (2) Soil, Water and Environment Research Institute, Agriculture Research Center, Giza, \\ Egypt \\ *Corresponding author email: darwesh.abeed@gmail.com
}

Received: Sep. 3, 2020

Accepted: Oct. 15,2020

\begin{abstract}
ABSTRAC: A field experiment was conducted at El-Kanater Horticultural Research Station, Egypt in the seasons of 2017 and 2018 to study raised bed cultivation system for apple trees production is a new technique nowadays. The obtained results indicated that raised bed $200 \mathrm{~cm}$ (i.e. $100 \mathrm{~cm}$. from each side of the pseudo stems) was superior than $100 \mathrm{~cm}$ (i.e.50 cm. from each side of the pseudo stems) which was better than flat irrigation. The treatment of raised bed $200 \mathrm{~cm}$ significantly increased water use efficiency, vegetative growth parameters, yield about (21 and $20 \%$ both seasons), fruit quality, leaf nutrient composition (N, P and K) and root distribution. Raised bed $200 \mathrm{~cm}$ treatment effectively saves $23.6 \%$ and $23.2 \%$ (1439.5 and $1452.1 \mathrm{~m} 3 / \mathrm{fed} . /$ year) through the two studied seasons. So, raised bed $200 \mathrm{~cm}$ treatment is recommended for apple growers on clay loamy soil.
\end{abstract}

Key words: Apple trees, Raised Bed Cultivation, Water Use Efficiency, Fruit set and Yield.

\section{INTRODUCTION}

"Anna" apple (Malus domestica, Barkh) is considered one of the leading apple cultivars in Egypt, being of low chilling requirements. It needs chilling about $300-350 \mathrm{hrs}$ below $7.2^{\circ} \mathrm{C}$ to break their bud dormancy (Zayan and Morsy, 1989). The cultivated area of "Anna" apple cultivar is being increased rapidly especially during the last three decades to reach 71544 feddan in 2017 which produced 716271 ton according to Economic Affairs Sector (2017). Considering the increasing world population and climate change, water can become a limiting factor for agriculture (Ashraf, 2010). In this context, increase water-use efficiency is a vital issue for socio-economic development in many regions. More efficient water use is possible with improvements in plant breeding to enable crops to grow successfully in drought environments and in irrigation management, as well as in irrigation systems (Thompson et al., 2009). Water availability is the most limiting factor for rising production of agriculture and an important factor for production, especially for apple in Egypt as well as arid and semi-arid regions as they face shortage in water demands of agriculture and other activities.

Irrigation is necessary to multiply crops and to increase yields. High quality yields can be produced profitably when irrigation systems are well managed. However, because roots grow towards the moist layers in the soil, it is important to consider both the fruit- and root growth of apple trees when scheduling irrigation to improve/manipulate the root growth as fruit- and root growth are dependent on one another. (Hillel, 2004) Irrigation scheduling, i.e. when and how much water to apply, is important to manage the available water for irrigation 
efficiently in order to decrease water losses (through transpiration and evaporation) and increase both vegetative and root growth (Tanner and Sinclair, 1983) The soil water content distribution throughout the soil profile will influence the water uptake by roots. Green and Clothier (1999) proved that $70 \%$ of the water uptake by apple tree roots occurred in the $\mathbf{0 - 0 . 4} \mathrm{m}$ soil depth layer when the surface soil water was distributed uniformly. Sokalska et al., (2009) stated that mature apple tree roots withdraw soil water easily close to the tree trunk where water is readily available. When water is depleted close to the tree trunk, roots will grow to areas with more available soil water after the depletion of soil water close to the tree trunk. At the farm level, farmers try to increase production by applying irrigation; unfortunately, they use a traditional technique that requires large amounts of water. Surface irrigation is characterized by lower water application efficiency ( 45 to $50 \%$ ) compared to the other methods, mainly because of water loss which is due to deep percolation and evapotranspiration. Farmers are usually seen to over-irrigate their fields, which leads to greater losses leading to profile drainage, which in turn increases water storage that cannot be taken up by crops. Consequently, optimal irrigation application during the growing season is important for increasing apple productivity per unit of applied water without additional costs (Swelam and Atta, 2011).

Raised bed planting method is advantageous in areas where ground water level is receding and herbicideresistant weeds are creating a problem. When using the raised bed planting method technology, higher yield, lower water application and higher gross production water use indices can be achieved Bhuyan et al., (2016). Deficient irrigation applications are probably largely due to reduced deep percolation losses but also to evaporation (Humphreys et al., 2004). Farré and Faci (2006) reported that the relationship between yield and irrigation water applied is economically more important than the relationship between yield and evapotranspiration. Karrou et al., (2012) reported that the applied irrigation water for raised bed (RB) techniques and treatments included the farmers' normal surface irrigation practice (FT), were 3841 and $5369 \mathrm{~m} 3 / \mathrm{ha}$. The use of the RB technique increased water productivity for the farmers' usual water management practice. Raised bed planting method has been shown to improve water distribution and efficiency, fertilizer use efficiency and reduces weed infestation (Hobbs et al., 1998).

An improved surface irrigation technique is affirming farmers a practical and more sustainable alternative to conventional irrigation systems which tend to be highly inefficient and waste already-scarce water resources. Raisedbed where trees are planted on ridges and irrigation water is applied to the bottom of furrows -Instead of spreading water over the entire surface area - the practice most commonly applied by farmers - raised-bed planting collects water more efficiently, applying this precious resource where it is most needed. Therefore, the aim of this study is the effect of raised bed technique and productivity, and yield of apple trees as well as some yield-water relationships.

\section{MATERIALS AND METHODS}

The present investigation was undertaken during the two successive seasons of 2017 and 2018 respectively, in addition to preparation season during 2016 at the Experimental Farm at ElKanater Horticultural Research Station, Qalyoubeia Governorate, Egypt (Latitude: $30^{\circ}$. $19 \mathrm{~N}$ Longitude: $31^{\circ}$. 11 Elevation: 
$16.9 \mathrm{~m}$ ) on fruitful trees of "Anna" apple (Malus domestica, Borkh) budded on MM106 rootstock. The selected trees were about twelve years old grown on clay loamy soil at planting distance at $4 \mathrm{x}$ 4 meters. Trees were carefully selected as being healthy and approximately uniform in their vigour, shape and size and received regularly the common horticultural practices in the region.

The experimental design was a randomized complete block with five replicates for each treatment and two trees for each replicate.
Before treatments applications soil samples of experimental soil were takes at soil depths of $0-30,30-45$ and $45-60 \mathrm{~cm}$ to determine main soil physical parameters. Particle size distribution was conducted using the pipette method according to Klute (1986). Soil moisture constants were determined using the pressure membrane apparatus Stackman (1966). The obtained data are recorded in Tables (1 and 2). Meteorological data for the Agricultural Research Station are shown in (Table 3).

Table (1): Physical properties of the experiment soil.

\begin{tabular}{|l|c|}
\hline \multicolumn{1}{|c|}{ Particle size distribution (\%): } & Value \\
\hline Clay & 32.2 \\
\hline Silt & 33.5 \\
\hline Fine sand & 33.2 \\
\hline Coarse sand & 1.1 \\
\hline Texture class & Clay loamy \\
\hline
\end{tabular}

Table (2): Some soil - water parameters and bulk density.

\begin{tabular}{|c|c|c|c|c|c|c|c|}
\hline \multirow{2}{*}{ Depth } & \multicolumn{2}{|c|}{$\begin{array}{c}\text { Field capacity } \\
\text { (FC) }\end{array}$} & \multicolumn{2}{c|}{$\begin{array}{c}\text { Wilting Point } \\
\text { (WP) }\end{array}$} & \multicolumn{2}{c|}{$\begin{array}{c}\text { Available water } \\
\text { (AW) }\end{array}$} & \multirow{2}{*}{$\begin{array}{c}\text { Bulk density } \\
\text { (BD) } \mathbf{g} / \mathrm{m}^{3}\end{array}$} \\
\cline { 2 - 7 } & $\begin{array}{c}\text { \% by } \\
\text { weight }\end{array}$ & $\mathrm{cm}$ & $\begin{array}{c}\text { \% by } \\
\text { weight }\end{array}$ & $\mathrm{cm}$ & $\begin{array}{c}\text { \% by } \\
\text { weight }\end{array}$ & $\mathrm{cm}$ & \\
\hline $0-15$ & 39.2 & 7.22 & 18.5 & 3.38 & 20.7 & 3.45 & 1.23 \\
\hline $15-30$ & 37.3 & 7.18 & 17.9 & 3.37 & 19.4 & 3.57 & 1.25 \\
\hline $30-45$ & 35.2 & 6.77 & 16.6 & 3.23 & 18.6 & 3.51 & 1.30 \\
\hline $45-60$ & 34.1 & 6.81 & 15.9 & 3.28 & 18.2 & 3.53 & 1.34 \\
\hline Total & & 27.98 & & 13.92 & & 14.06 & \\
\hline
\end{tabular}

FC: moisture at $33 \mathrm{KPa}$ (0.33 bar) moisture tension.

WP: moisture at $1.5 \mathrm{MPa}$ (15 bar) moisture tension.

AW = FC-WP

Table (3): Meteorological data in 2017 and 2018 seasons.

\begin{tabular}{|c|c|c|c|c|c|c|c|c|c|c|c|c|}
\hline Season & \multicolumn{6}{|c|}{2017} & \multicolumn{6}{|c|}{2018} \\
\hline Month & $\begin{array}{c}\mathrm{T} . \\
\max \end{array}$ & T. $\min$ & W.S & R.H & S.S & R.F & $\begin{array}{c}\mathrm{T} . \\
\max \end{array}$ & T. $\min$ & w.S & R.H & S.S & R.F \\
\hline Mar. & 24.8 & 10.4 & 3.6 & 51.3 & 8.6 & 4.2 & 28.7 & 11.7 & 2.5 & 42.3 & 8.9 & 1.1 \\
\hline Apr. & 28.9 & 12.4 & 3.9 & 45.4 & 9.6 & 28.2 & 30.8 & 14.2 & 2.6 & 41.0 & 9.4 & 28.3 \\
\hline May & 34.5 & 17.4 & 3.1 & 37.1 & 10.8 & 9.6 & 35.6 & 19.2 & 3.1 & 38.0 & 10.9 & 5.5 \\
\hline Jun. & 38.0 & 20.3 & 3.2 & 36.2 & 12.0 & 1.9 & 37.8 & 21.2 & 3.1 & 36.1 & 12.5 & 0.1 \\
\hline Jul. & 40.1 & 22.8 & 3.0 & 37.6 & 11.7 & 0.0 & 39.0 & 22.4 & 3.0 & 40.8 & 11.5 & 0.0 \\
\hline Aug. & 38.6 & 22.8 & 2.8 & 42.6 & 11.1 & 0.0 & 38.4 & 22.5 & 2.9 & 44.6 & 11.6 & 0.0 \\
\hline Sep. & 36.2 & 19.8 & 2.8 & 45.9 & 10.3 & 0.0 & 36.3 & 21.0 & 2.7 & 47.1 & 10.7 & 0.0 \\
\hline Oct. & 30.4 & 16.7 & 2.6 & 52.2 & 9.2 & 14.4 & 31.7 & 18.1 & 2.8 & 50.8 & 9.8 & 4.8 \\
\hline
\end{tabular}


M. A. Fathi, et al.,

Where: T.max. , T.min.= maximum and minimum temperatures ${ }^{\circ} \mathrm{C} ; \mathrm{W} . S=$ wind $\mathrm{speed}(\mathrm{m} / \mathrm{sec})$; $\mathbf{R} . \mathbf{H}=$ relative humidity (\%); S.S= actual sun shine (hour); $\mathbf{S} . \mathbf{R}=$ solar radiation (cal $/ \mathrm{cm}^{2} / \mathrm{day}$ ). $\mathbf{R F}=$ rainfall ( $\mathrm{mm}$ / month).[Data were obtained from the agrometeorological Unit at SWERI, ARC]

Irrigation treatments used in this study were as follows:

1. $\mathrm{l}_{1}$ : Cultivation in flat (control).

2. $\mathrm{I}_{2}$ : Cultivation on raised bed (RB) 100 $\mathrm{cm}$ (i.e. $50 \mathrm{~cm}$. from each side of the pseudo stems).

3. $\mathrm{I}_{3}$ : Cultivation on raised bed (RB) 200 $\mathrm{cm}$ (i.e. $100 \mathrm{~cm}$. from each side of the pseudo stems).

Irrigation started after trees received the winter irrigation on March i.e., starting from bud swelling stage. Irrigation was done when moisture reached the relevant level to determine available soil water retained in the soil in each treatment. Soil moisture was determined grave metrically on oven dry basis of soil samples taken to a depth of $15 \mathrm{~cm}$ up to $60 \mathrm{~cm}$. Water consumption was computed as the differences of soil moisture content in soil samples taken prior to 48 hours after irrigation. The quantity of irrigation water applied to each "Apple" tree per feddan $\left(\mathrm{m}^{3}\right)$ in the different treatments from March to October during each growing season was calculated.

\section{Water relations:}

\subsection{Calculation of water consumptive use (WCU)}

Water consumptive use (WCU) or actual evapotranspiration (ETc) values were calculated for each irrigation treatment using the following formula (Israelsen and Hansen, 1962).

$$
W C U=\sum_{i=1}^{i=4} \frac{\left(\theta_{2}-\theta_{1}\right)}{100} \times B d \times D
$$

Where:

$\mathrm{WCU}=$ seasonal water consumptive use (cm),

$\Theta_{2}=$ soil moisture content after irrigation (on mass basis, \%),
$\Theta_{1}=$ soil moisture content before irrigation (on mass basis, \%),

$\mathrm{Bd}=$ soil bulk density $\left(\mathrm{g} / \mathrm{cm}^{3}\right)$,

$D=$ depth of soil layer $(15 \mathrm{~cm}$ each), and

$\mathrm{i}=$ number of soil layer.

1.2. Irrigation Water Applied (IWA):

Submerged flow orifice with fixed dimension was used to measure the amount of water applied, according to Michael, (1978) as the following equation: $\mathbf{Q}=\mathbf{C A} \sqrt{2 \mathrm{gh}}$

Where:

$Q=$ discharge through orifice, $(1 / \mathrm{sec})$.

$C=$ coefficient of discharge, $(0.61)$.

$A=$ cross-sectional area of the orifice, $\mathrm{cm}^{2}$.

$\mathrm{g}=$ acceleration due to gravity, $\mathrm{cm} / \mathrm{sec}^{2}$ $\left(981 \mathrm{~cm} / \mathrm{sec}^{2}\right)$.

$\mathbf{h}=$ pressure head, causing discharge through the orifice, $\mathrm{cm}$.

\subsection{Water utilization efficiency (W.Ut.E):}

The production of apple fruits by one cubic meter of irrigation water (fruit yield in $\mathrm{kg} / \mathrm{feddan} / \mathrm{m} 3$ water applied /feddan), as affected by different treatments was calculated by the following equation Jensen 1983:

W.Ut.E $=\frac{\text { Fruits yield }(\mathrm{kg}) / \text { feddan }}{\text { Seasonal AIW }(\mathrm{m} 3 / \text { water applied }) / \text { feddan }}$

\section{Vegetative growth measurements}

Four main branches, in different directions of each replicate were labeled. All current shoots developed on those branches on Aug. were used for measuring vegetative growth parameters as follows: a) Shoot length (cm), b) Number of leaves per shoot and c) Leaf area $\left(\mathrm{cm}^{2}\right)$ using Li-core $\mathbf{3 1 0 0}$ area meter.

\section{Fruiting parameters}


3.1. Fruit set (\%): Fruit set $\%$ was estimated by the following equation according to Westwood (1978).

Fruit set $(\%)=\frac{\text { Number of developed fruitlets }}{\text { Total number of flowers at full bloom }} \times 100$

3.2. Yield: At harvest time, yield of each tree was recorded as either $\mathrm{kg}$ per tree or ton per feddan or number of fruits /tree during the two seasons of study. Samples of twenty fruits from each replicate under treatment were randomly collected at harvest and the following characters were determined as follows:

\section{Fruit quality.}

\subsection{Physical fruit properties}

Fruit weight $(\mathrm{g})$, fruit volume $\left(\mathrm{cm}^{3}\right)$, height $(\mathrm{cm})$, diameter $(\mathrm{cm})$, fruit shape index and fruit firmness, which was determined by Magness and Taylor (1925), pressure tester using 7/18 inch plunger two reading were taken on the flesh of each fruit.

\subsection{Chemical fruit properties}

a) Total soluble solids (\%) in fruit juice was determined by using hand refractometer.

b) Titratation table acidity (\%) was measured according to A.O.A.C. (1990) and Vogel (1968).

c) Total soluble solids/acidity ratio was calculated.

\section{Leaf nutrient composition}

Twenty mature leaves at mid-shoot on mid August of both seasons were collected randomly, and washed with tap water followed by distilled water then oven dried at $70{ }^{\circ} \mathrm{C}$ to constant weight and prepared for the determination of leaf minerals content. Total nitrogen was determined by the micro-kjeldahl method according to Cottenie et al. (1982). Total phosphorus was determined and measured using a spectrophotometer (Spectronic 20) to the method described by Murphy and Reily (1962). Total potassium content was determined in the acid digest using Atomic Absorption Spectrophotometer method for plant analysis according to method described by Chapman and Pratt (1961).

\section{Root distribution:}

Samples of roots were taken in November 2018 at 0-30, 30-60 and 60-90 cm depth at 50, 100 and $150 \mathrm{~cm}$ from the tree trunk in the four directions. Root length (< $2 \mathrm{~mm}$ and $>2 \mathrm{~mm}$ root thick) was assessed (cm), root number and root dry weight (g) as $\mathrm{g} /$ hole $\left(1750.8 \mathrm{~cm}^{3}\right.$ or $1.628 \mathrm{~kg}$ soil) according to Cahoon et al. (1959) and Ford (1962).

\section{Statistical analysis}

Data were statistically analyzed according to the analysis of variance as described by Waller and Duncan (1969).

\section{RESULTS AND DISCUSSION}

\section{Soil water relations:}

1.1. Irrigation water Applied (IWA, $\mathrm{m}^{3} / \mathrm{fed}$ ):

Amount of applied irrigation water throughout the growing season for different treatments were presented in Table (4) The highest seasonal values were recorded under normal surface irrigation practice a part comparing with raised bed (RB) techniques treatments in the two growing seasons.

The total amount of irrigation water applied for apple trees in the first season was $4677.9,5130.1$ and $6117.4 \mathrm{~m}^{3}$ fed ${ }^{-1}$ for the raised bed (RB) techniques 200, 100 $\mathrm{cm}$ and normal surface irrigation practice (flat). In the second season, these quantities were 4828.1, 5242.9 and 6280.2 $\mathrm{m}^{3} \mathrm{fed}^{-1}$ respectively. Also, results revealed that raised bed $\left(I_{3}\right) 200 \mathrm{~cm}$ irrigation treatments could save about $23.5 \%$ and $23.1 \%$ of the applied water, compared with $\left(I_{1}\right)$ in both growing seasons, respectively. In addition, under 
raised bed $\left(I_{2}\right) 100 \mathrm{~cm}$ irrigation treatment the same trend was noticed with reduction percentages values reached to $16.1 \%$, as compared with flat $\left(I_{1}\right)$. The results showed that the water requirements in the second season are higher than for first season, maybe due to increasing the weather temperature in second season. The applied water was higher under (flat) in comparison with raised bed techniques. The present results are in harmony with those previously mentioned by Hobbs et al., 1998, Humphreys et al., 2004, Sayre and Hobbs, (2004) Karrou et al., (2012) and Moursi and Yehia (2016) they revealed that, the use of raised bed (RB) planting method technique improved water distribution and increased water productivity efficiency as well as It can lead to saving applied water as compared with normal surface irrigation practice.

\subsection{Monthly applied irrigation water}

Results in Fig. 1 show that monthly applied water values began to raise during March then gradually increased to reach its maximum during June and July. Under raised bed (RB) techniques $(200 \mathrm{~cm})$, maximum applied irrigation water values of 777.5 and $800 \mathrm{~m}^{3} / \mathrm{fed}$. occurred in July in the $1^{\text {st }}$ and $2^{\text {nd }}$ seasons, respectively. While under normal surface irrigation practice (flat), maximum applied irrigation water values of 1007.4 and $1034.6 \mathrm{~m}^{3} / \mathrm{fed}$. occurred also in July in the same seasons, respectively. This might be due to the increase of vegetative growth rate and the raise of temperature during summer season. Afterwards, the daily applied irrigation water values, gradually decreased. Such pattern was attained by apple trees. In this concern, during April little growth was appeared, but towards the end of October the trees growth rate slowed down. Ibrahim (1981) concluded that the increase in evapotranspiration by maintaining soil moisture at a high level is attributed to excess available water in the root zone.

Table (4): Amounts of applied irrigation water $\left(\mathrm{m}^{3} /\right.$ tree and $\left(\mathrm{m}^{3} / \mathrm{fed}\right)$ for apple trees as affected by irrigation treatments in clay loamy during 2017-2018 growing season

\begin{tabular}{|c|c|c|c|c|c|c|}
\hline Irrigation treatment & \multicolumn{2}{c|}{$\mathrm{I}_{1}$} & \multicolumn{2}{c|}{$\mathrm{I}_{2}$} & \multicolumn{2}{c|}{$\mathrm{I}_{3}$} \\
\hline Month & $\mathrm{m}^{3} /$ tree & $\mathrm{m}^{3} / \mathrm{fed}$ & $\mathrm{m}^{3} /$ tree & $\mathrm{m}^{3} / \mathrm{fed}$ & $\mathrm{m}^{3} /$ tree & $\mathrm{m}^{3} /$ fed \\
\hline \multicolumn{7}{|c|}{2017} \\
\hline March & 2.45 & 641.1 & 2.22 & 582.1 & 2.14 & 561.5 \\
\hline April & 2.16 & 566.1 & 1.72 & 450.0 & 1.39 & 363.9 \\
\hline May & 3.41 & 892.6 & 2.70 & 708.7 & 2.59 & 679.8 \\
\hline June & 3.75 & 982.6 & 3.18 & 833.8 & 2.88 & 753.7 \\
\hline July & 3.85 & 1007.4 & 3.26 & 855.0 & 2.97 & 777.5 \\
\hline August & 3.49 & 915.5 & 3.09 & 810.2 & 2.65 & 695.6 \\
\hline September & 2.34 & 612.9 & 1.81 & 473.4 & 1.79 & 469.0 \\
\hline October & 1.91 & 499.2 & 1.59 & 416.9 & 1.44 & 376.9 \\
\hline Total & 6117.4 & & 5130.1 & & 4677.9 \\
\hline \multicolumn{7}{|c|}{2018} \\
\hline March & 2.51 & 657.2 & 2.27 & 594.9 & 2.21 & 577.8 \\
\hline April & 2.21 & 580.3 & 1.76 & 459.9 & 1.48 & 389.0 \\
\hline
\end{tabular}


Comparative study on the effect of different flood irrigation methods and

\begin{tabular}{|c|c|c|c|c|c|c|}
\hline May & 3.50 & 916.7 & 2.76 & 724.3 & 2.67 & 699.5 \\
\hline June & 3.85 & 1009.1 & 3.25 & 852.1 & 2.96 & 775.6 \\
\hline July & 3.95 & 1034.6 & 3.34 & 873.8 & 3.05 & 800.0 \\
\hline August & 3.59 & 940.2 & 3.16 & 828.0 & 2.73 & 715.8 \\
\hline September & 2.40 & 629.4 & 1.85 & 483.8 & 1.84 & 482.6 \\
\hline October & 1.96 & 512.7 & 1.63 & 426.1 & 1.48 & 387.8 \\
\hline Total & & 6280.2 & & 5242.9 & & 4828.1 \\
\hline
\end{tabular}
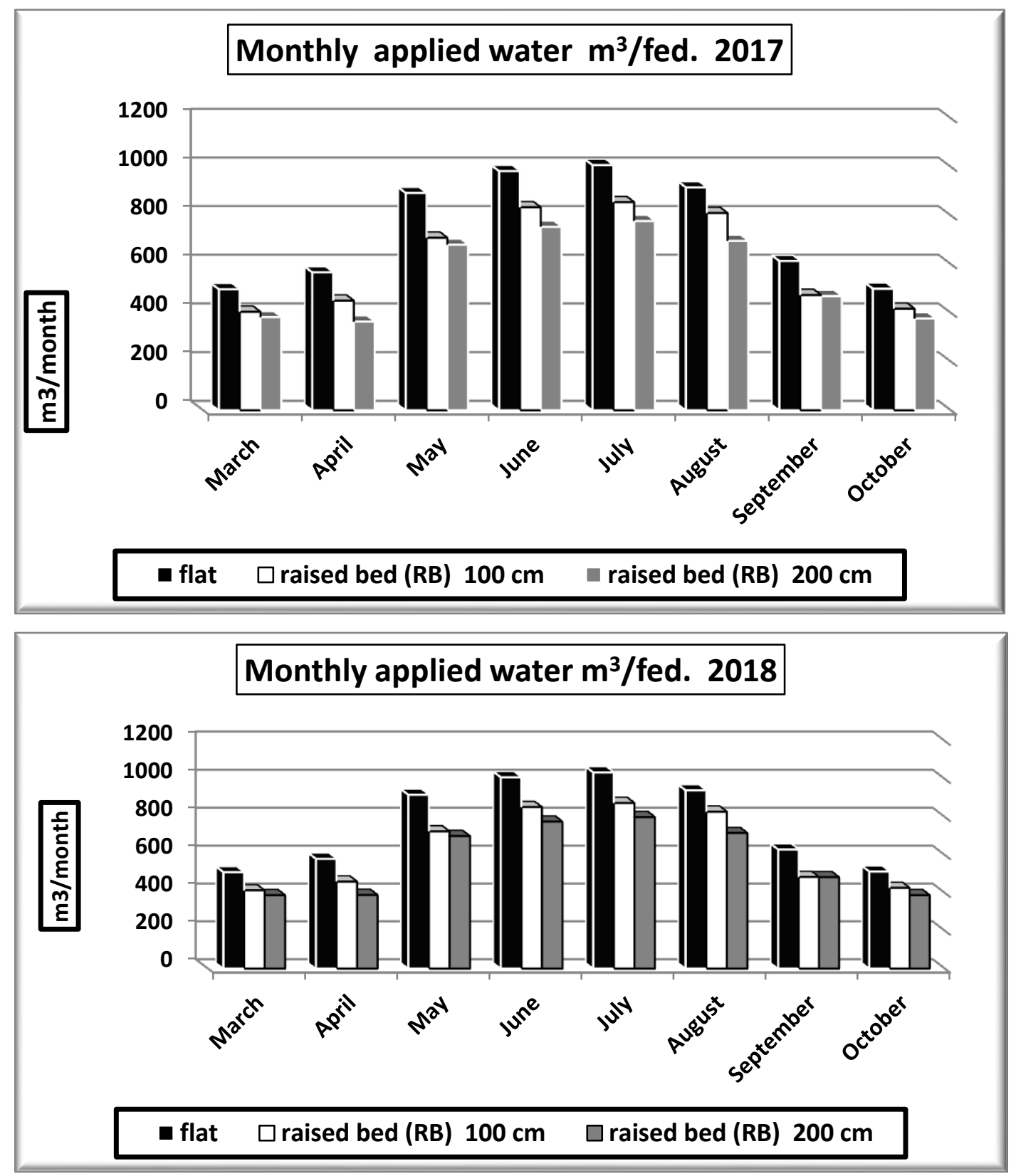

Fig. 1: Monthly applied irrigation water under flooding irrigation systems in 2017 and 2018 seasons. 


\subsection{Water utilization efficiency} (W.Ut.E):

In addition, data in Fig. 2 show water use efficiency of apple trees as affected by irrigation methods. Data show that raised bed (RB) $200 \mathrm{~cm}$. $\left(I_{3}\right)$ has the most significant rank of efficiency (2.06 and 2.04 fruits $\mathrm{Kg} / \mathrm{m}^{3}$ ) water consumed, while it decreased in case of flat irrigation system $\left(I_{1}\right)$ and reached $(1.24$ and 1.31 fruits $\mathrm{Kg} / \mathrm{m}^{3}$ ) water consumed in the two studied seasons respectively. Obtained results in this concern are coincident with that reported by several researchers, Swelam and Atta (2011), Karrou et al., (2012) and Bhuyan et al. (2016).

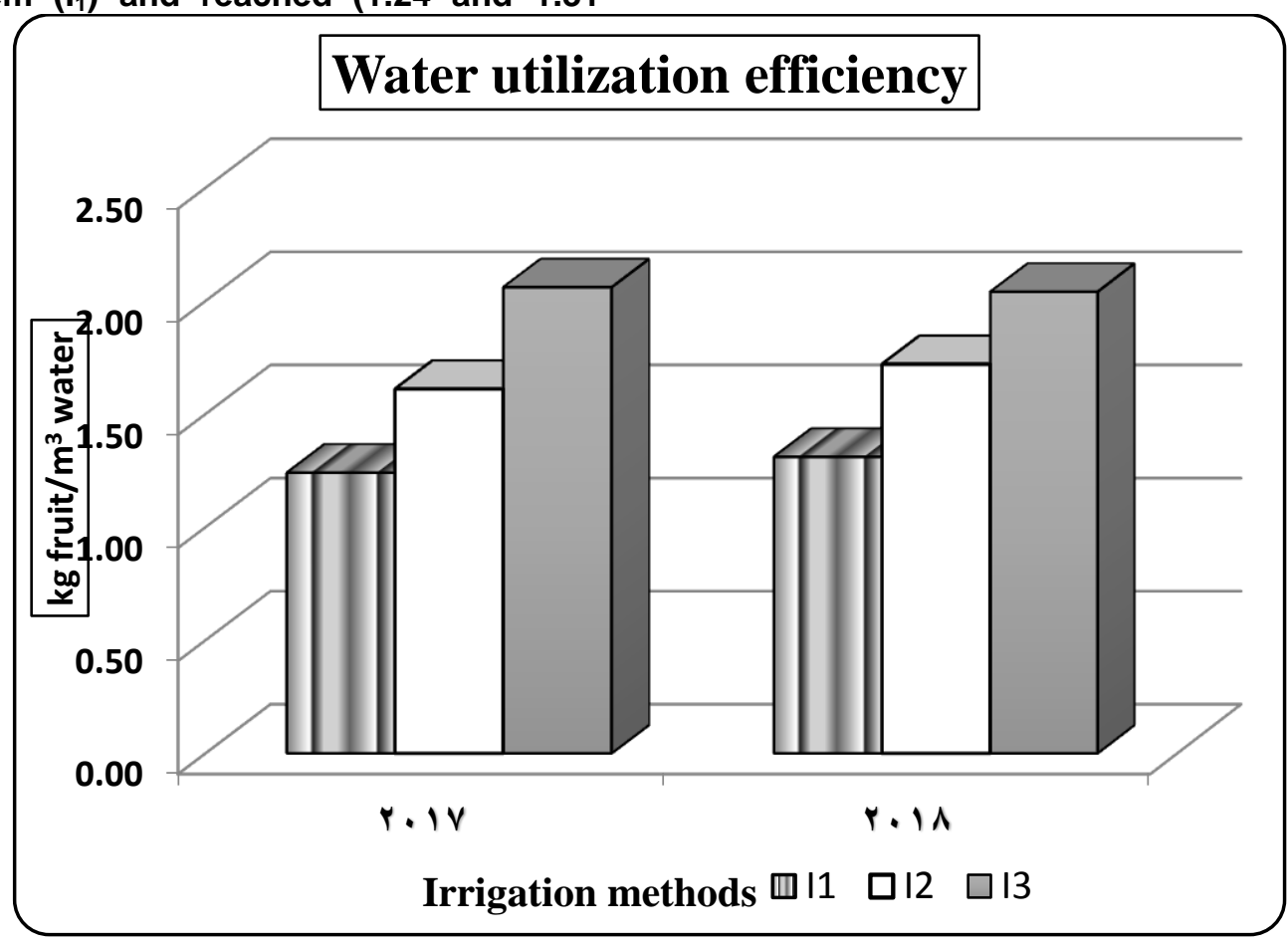

Fig. 2: Effect of irrigation methods on water utilization efficiency (W.Ut.E) $\mathrm{kg} / \mathrm{m} 3$ of apple trees.

\section{Vegetative measurements}

Table (5) illustrate vegetative growth parameters, i.e. shoot length $(\mathrm{cm})$, number of leaves/shoot and leaf area $\left(\mathrm{cm}^{2}\right)$. The present results show that, $I_{3}$ (raised bed $200 \mathrm{~cm}$.) significantly induced the highest vegetative growth characteristics of apple trees i.e. 48.48 and $49.92 \mathrm{~cm}$. of shoot length, 38.53 and 39.14 number of leaves / shoot as well as 40.87 and $42.64 \mathrm{~cm}^{2}$ of leaf area through 2017 and 2018 seasons respectively compared to $I_{1}$ or $I_{2}$. However, $I_{2}$ (raised bed $100 \mathrm{~cm}$.) significantly induced higher vegetative growth than $l_{1}$ flat irrigation practice. These results are in a complete agreement with those observed by Tanner and Sinclair (1983), Hillel, (2004) and Kabeel et al., (2013) on pear.

\section{Fruit set, yield and yield components:}

Data in Table (6) clear the effect of irrigation practices on fruit set, fruit yield ( $\mathrm{Kg} /$ tree and Ton/fed.) as well as number 
of fruits/trees. The present results show obvious and significantly effect of $I_{3}$ (raised bed $200 \mathrm{~cm}$.) on fruit set (14.58 and $15.66 \%$ ), 37.87 and $39.48 \mathrm{Kg} /$ tree, 9.92 and 10.34 Ton/fed as well as 268.4 and 276.5 fruits/tree compared to $I_{2}$ (raised bed $100 \mathrm{~cm}$.) which was superior and significantly than $I_{1}$ (flat practice). in this respect, obtained results regarding the response of abovementioned four Table 5: Vegetative growth measurements as affect by irrigation method.

\begin{tabular}{|c|c|c|c|c|c|c|}
\hline \multirow{2}{*}{ Treatments } & \multicolumn{2}{|c|}{ Shoot length (cm) } & \multicolumn{2}{c|}{ No. of leaves/shoot } & \multicolumn{2}{c|}{ Leaf area (cm2) } \\
\cline { 2 - 7 } & 2017 & 2018 & 2017 & 2018 & 2017 & 2018 \\
\hline$I_{1}$ & $43.20 \mathrm{C}$ & $44.39 \mathrm{C}$ & $29.17 \mathrm{C}$ & $30.81 \mathrm{C}$ & $33.83 \mathrm{C}$ & $37.22 \mathrm{C}$ \\
\hline $\mathrm{I}_{2}$ & $45.53 \mathrm{~B}$ & $46.28 \mathrm{~B}$ & $35.03 \mathrm{~B}$ & $36.07 \mathrm{~B}$ & $37.43 \mathrm{~B}$ & $39.38 \mathrm{~B}$ \\
\hline $\mathrm{I}_{3}$ & $48.48 \mathrm{~A}$ & $49.92 \mathrm{~A}$ & $38.53 \mathrm{~A}$ & $39.14 \mathrm{~A}$ & 40.87A & 42.64A \\
\hline
\end{tabular}

Table 6: Fruit set, yield and yield components as affect by irrigation method

\begin{tabular}{|c|c|c|c|c|c|c|c|c|}
\hline \multirow{2}{*}{ Treatments } & \multicolumn{2}{|c|}{ Fruit set (\%) } & \multicolumn{2}{c|}{ Yield (kg/tree) } & \multicolumn{2}{c|}{ Yield (ton/fed) } & \multicolumn{2}{c|}{ No. fruit/tree } \\
\cline { 2 - 8 } & 2017 & 2018 & 2017 & 2018 & 2017 & 2018 & 2017 & 2018 \\
\hline $\mathrm{I}_{1}$ & $12.57 \mathrm{C}$ & $13.70 \mathrm{C}$ & $31.41 \mathrm{C}$ & $32.88 \mathrm{C}$ & $8.23 \mathrm{C}$ & $8.62 \mathrm{C}$ & $251.3 \mathrm{C}$ & $256.1 \mathrm{C}$ \\
\hline $\mathrm{I}_{2}$ & $13.17 \mathrm{~B}$ & $14.35 \mathrm{~B}$ & $34.29 \mathrm{~B}$ & $36.05 \mathrm{~B}$ & $8.99 \mathrm{~B}$ & $9.44 \mathrm{~B}$ & $263.4 \mathrm{~B}$ & $270.0 \mathrm{~B}$ \\
\hline $\mathrm{I}_{3}$ & $14.58 \mathrm{~A}$ & $15.66 \mathrm{~A}$ & $37.87 \mathrm{~A}$ & $39.48 \mathrm{~A}$ & $9.92 \mathrm{~A}$ & $10.34 \mathrm{~A}$ & $268.4 \mathrm{~A}$ & $276.5 \mathrm{~A}$ \\
\hline
\end{tabular}

4. Fruit physical and chemical properties as affected by irrigation practice:

Data in Tables ( 7 and 8 ) show a superior increase effect of $\mathrm{I}_{3}$ treatment (raised bed $200 \mathrm{~cm}$.) on fruit physical properties i.e. fruit weight (141.1 and $142.8 \mathrm{~g})$, volume (131.4 and $\left.133.5 \mathrm{~cm}^{3}\right)$, fruit firmness (12.17 and $12.62 \mathrm{lb} /$ inch $^{2}$ ), height $(6.76$ and $6.85 \mathrm{~cm}$.), diameter $(6.76$ and $6.78 \mathrm{~cm}$.) as well as fruit shape index (1.00 and 1.01) with exception of some condition. Also, $\mathrm{I}_{3}$ treatment significantly increased TSS percentage (12.63 and $12.91)$ as well as TSS/acidity ratio (28.70 and 28.88), while, decreased acidity percentage $(0.440$ and 0.447$)$ compared to $I_{2}$ which was better than $I_{1}$ (flat fruiting parameters i.e. fruit set \%, fruit yield ( $\mathrm{Kg} /$ tree and Ton/fed.) as well as number of fruits per tree to the investigated irrigation treatments under study were supported by the findings of Hussein (1998) on apple and Fathi (1999 ( $a$ and $b$ ) on pear and Hussein and Eid (2013) on plum and kabeel et al.,(2013) on pear trees. practice). Fruit quality results under irrigation regimes are in agreement with the findings of Hilgeman and Sharo (1970) on orange, Fathi (1999-a) on pear Ali and Gobran (2002) on Washington Navel orange, they mentioned that higher applied water decreased TSS, total acidity and ascorbic acid contents.

\section{Leaf nutrient composition:}

The present results in Table (9) clear the effect of irrigation practices on nutrient composition of apple leaves. There are insignificant different between the two studied raised bed practices $\left(I_{3}\right.$ and $\mathrm{I}_{2}$ ). Otherwise, there are significant and noticeable decrease in apple leaves composition of nitrogen (1.700 and 1.757 
M. A. Fathi, et al.,

$\%)$, phosphorus (0.293 and $0.309 \%)$ as well as potassium (1.593 and $1.805 \%)$ with flat irrigation practice $\left(I_{1}\right)$. That also cleared by Hussien, et al. (2013) on plum and Fathi (1999-b) on pears. Also, Green and Clothier (1999) proved that $70 \%$ of water uptake by apple tree roots Table 7: Fruit physical properties as affect by irrigation method

\begin{tabular}{|c|c|c|c|c|c|c|c|c|c|c|c|c|}
\hline \multirow[t]{2}{*}{ Treatments } & \multicolumn{2}{|c|}{$\begin{array}{l}\text { Fruit weight } \\
\qquad(\mathrm{g} .)\end{array}$} & \multicolumn{2}{|c|}{$\begin{array}{l}\text { Fruit volume } \\
\qquad(\mathrm{cm} 3)\end{array}$} & \multicolumn{2}{|c|}{$\begin{array}{l}\text { F. firmness } \\
\text { (lb/inch2) }\end{array}$} & \multicolumn{2}{|c|}{$\begin{array}{l}\text { Fruit height } \\
\text { (cm) }\end{array}$} & \multicolumn{2}{|c|}{$\begin{array}{c}\text { Fruit } \\
\text { diameter } \\
\text { (cm) }\end{array}$} & \multicolumn{2}{|c|}{ F. shape index } \\
\hline & 2017 & 2018 & 2017 & 2018 & 2017 & 2018 & 2017 & 2018 & 2017 & 2018 & 2017 & 2018 \\
\hline$I_{1}$ & $125.0 \mathrm{C}$ & $128.4 \mathrm{C}$ & 116.2B & 115.6B & 10.41B & $10.80 \mathrm{~B}$ & $5.32 \mathrm{C}$ & $5.69 \mathrm{~B}$ & $5.90 \mathrm{C}$ & $5.94 \mathrm{~B}$ & $0.90 \mathrm{~B}$ & $0.96 \mathrm{~B}$ \\
\hline $\mathbf{I}_{2}$ & $130.2 B$ & 133.5B & 115.7B & 117.5B & 11.98AB & $12.51 \mathrm{AB}$ & $6.58 \mathrm{~B}$ & $6.88 \mathrm{~A}$ & $6.52 \mathrm{~B}$ & $6.70 \mathrm{~A}$ & $1.01 \mathrm{~A}$ & $1.03 \mathrm{~A}$ \\
\hline$I_{3}$ & 141.1A & $142.8 \mathrm{~A}$ & 131.4A & $133.5 \mathrm{~A}$ & 12.17A & $12.62 \mathrm{~A}$ & 6.76A & $6.85 \mathrm{~A}$ & $6.76 \mathrm{~A}$ & $6.78 \mathrm{~A}$ & $1.00 \mathrm{~A}$ & $1.01 \mathrm{~A}$ \\
\hline
\end{tabular}

Table 8: Fruit chemical properties as affect by irrigation method.

\begin{tabular}{|c|c|c|c|c|c|c|}
\hline \multirow{2}{*}{ Treatments } & \multicolumn{2}{|c|}{ TSS (\%) } & \multicolumn{2}{c|}{ Acidity (\%) } & \multicolumn{2}{c|}{ TSS/Acidity } \\
\cline { 2 - 7 } & 2017 & 2018 & 2017 & 2018 & 2017 & 2018 \\
\hline $\mathrm{I}_{1}$ & $10.25 \mathrm{C}$ & $11.18 \mathrm{C}$ & $0.622 \mathrm{~A}$ & $0.609 \mathrm{~A}$ & $16.48 \mathrm{C}$ & $18.38 \mathrm{C}$ \\
\hline $\mathrm{I}_{2}$ & $12.30 \mathrm{~B}$ & $11.51 \mathrm{~B}$ & $0.513 \mathrm{~B}$ & $0.526 \mathrm{~B}$ & $23.98 \mathrm{~B}$ & $21.88 \mathrm{~B}$ \\
\hline $\mathrm{I}_{3}$ & $12.63 \mathrm{~A}$ & $12.91 \mathrm{~A}$ & $0.440 \mathrm{C}$ & $0.447 \mathrm{C}$ & $28.70 \mathrm{~A}$ & $28.88 \mathrm{~A}$ \\
\hline
\end{tabular}

Table 9: Leaf nutrient composition as affect by irrigation method.

\begin{tabular}{|c|c|c|c|c|c|c|}
\hline \multirow{2}{*}{ Treatments } & \multicolumn{2}{|c|}{$\mathrm{N}(\%)$} & \multicolumn{2}{c|}{$\mathrm{P}(\%)$} & \multicolumn{2}{c|}{$\mathrm{K}(\%)$} \\
\cline { 2 - 7 } & 2017 & 2018 & 2017 & 2018 & 2017 & 2018 \\
\hline $\mathrm{I}_{1}$ & $1.700 \mathrm{~B}$ & $1.757 \mathrm{~B}$ & $0.293 \mathrm{~B}$ & $0.309 \mathrm{~B}$ & $1.593 \mathrm{C}$ & $1.805 \mathrm{C}$ \\
\hline $\mathrm{I}_{2}$ & $2.186 \mathrm{~A}$ & $2.468 \mathrm{~A}$ & $0.330 \mathrm{~A}$ & $0.353 \mathrm{~A}$ & $1.983 \mathrm{~B}$ & $2.042 \mathrm{~B}$ \\
\hline $\mathrm{I}_{3}$ & $2.253 \mathrm{~A}$ & $2.520 \mathrm{~A}$ & $0.343 \mathrm{~A}$ & $0.361 \mathrm{~A}$ & $2.028 \mathrm{~A}$ & $2.107 \mathrm{~A}$ \\
\hline
\end{tabular}

\section{Root distribution:}

Root distribution of apple /MM106 root system was studied through 2017 and 2018 seasons as affected by irrigation practices. It's noticeable that length, number and dry weight of the root system at 50,100 and $150 \mathrm{~cm}$. from apple tree trunk as well as on $0-30,30-60$ and 60-90 cm. depth illustrated in Table (10). The present results clear that root distribution parameters (length, number occurred in the $0-40 \mathrm{~cm}$. soil depth layer when the surface soil water was distributed uniformly which is characterized by lower water efficiency 45- $50 \%$ (Swelam and Atta, 2011). 
the same finding was also cleared by Tanner and Sinclair (1983), Fathi (1999-b) Hussien, et al. (2013) on some fruit species, they showed that, the optimal irrigation application during the growing season is important for increasing roots

Table 10: Root distribution (length, number and dry weight) at 50,100 and $150 \mathrm{~cm}$. from the tree trunk and on $0-30,30-60$ and $60-90 \mathrm{~cm}$. depth as affect by irrigation method

\begin{tabular}{|c|c|c|c|c|c|c|c|c|c|c|c|c|c|}
\hline \multirow{4}{*}{$\begin{array}{c}\text { Irrigation } \\
\text { method (A) }\end{array} \mid$} & \multirow{4}{*}{$\begin{array}{c}\text { DISTANCE } \\
\text { cm(B) }\end{array}$} & \multicolumn{4}{|c|}{ Root length (cm) } & \multicolumn{4}{|c|}{ Root number } & \multicolumn{4}{|c|}{ Root dry weight(gm) } \\
\hline & & \multicolumn{12}{|c|}{ Root $<2 \mathrm{~mm}$, } \\
\hline & & \multicolumn{12}{|c|}{ root depth $\mathrm{cm}(\mathrm{C})$} \\
\hline & & $0-30$ & $30-60$ & $60-90$ & $\begin{array}{c}\text { Mean } \\
\text { (A) }\end{array}$ & $0-30$ & $30-60$ & $60-90$ & $\begin{array}{c}\text { Mean } \\
(\mathrm{A})\end{array}$ & $0-30$ & $30-60$ & $60-90$ & $\begin{array}{c}\text { Mean } \\
\text { (A) }\end{array}$ \\
\hline \multirow{3}{*}{$I_{1}$} & 50 & $568.6 \mathrm{c}$ & $420.1 \mathrm{~h}$ & $366.0 \mathrm{~m}$ & \multirow{3}{*}{$349.5 \mathrm{C}$} & $96.0 \mathrm{c}$ & 52.01 & $45.0 \mathrm{~m}$ & \multirow{3}{*}{$40.78 \mathrm{C}$} & $12.5 \mathrm{~d}$ & $9.8 \mathrm{~g}$ & $8.4 \mathrm{~h}$ & \multirow{3}{*}{$8.47 \mathrm{C}$} \\
\hline & 100 & $330.00 p$ & $314.0 q$ & $330.00 p$ & & $44.0 \mathrm{~m}$ & 35.0no & $22.0 p$ & & $10.0 f$ & $8.1 \mathrm{~h}$ & $6.1 \mathrm{j}$ & \\
\hline & 150 & 294.0s & $280.0 t$ & $272.5 u$ & & 38.0n & 25.00 & $10.0 q$ & & $8.0 \mathrm{~h}$ & $7.1 \mathrm{i}$ & $6.2 \mathrm{j}$ & \\
\hline \multirow{3}{*}{$I_{2}$} & 50 & $631.1 \mathrm{~b}$ & $466.3 f$ & $406.3 i$ & \multirow{3}{*}{$387.9 \mathrm{~B}$} & $100.5 b$ & $97.0 \mathrm{bc}$ & $68.3 i$ & \multirow{3}{*}{$64.38 \mathrm{~B}$} & $15.6 \mathrm{~b}$ & 12.3de & $10.5 f$ & \multirow{3}{*}{$10.59 \mathrm{~B}$} \\
\hline & 100 & $366.3 \mathrm{~m}$ & $348.5 n$ & 333.00 & & 63.3j & $56.8 \mathrm{k}$ & 51.316 & & $12.5 d$ & $10.1 f$ & $7.7 \mathbf{i}$ & \\
\hline & 150 & $326.3 p$ & $310.8 q r$ & $302.4 r$ & & $55.8 \mathrm{k}$ & 47.5Im & $39.1 \mathrm{n}$ & & $10.0 f$ & 8.9gh & 7.8hi & \\
\hline \multirow{3}{*}{$I_{3}$} & 50 & $757.4 a$ & $559.6 \mathrm{~d}$ & $487.5 \mathrm{e}$ & \multirow{3}{*}{ 465.A } & $112.0 a$ & 95.0d & $91.5 \mathrm{e}$ & \multirow{3}{*}{ 83.51A } & $18.3 a$ & $15.3 b$ & $13.1 \mathrm{c}$ & \multirow{3}{*}{$13.10 \mathrm{~A}$} \\
\hline & 100 & $439.6 \mathrm{~g}$ & 418.2hi & $399.6 \mathrm{j}$ & & $82.5 f$ & $78.5 \mathrm{~g}$ & $80.5 f$ & & $15.6 \mathrm{~b}$ & $12.7 d$ & $9.6 \mathrm{~g}$ & \\
\hline & 150 & 391.6k & 373.01 & $363.0 \mathrm{mn}$ & & $73.5 \mathrm{~h}$ & $70 \mathrm{hi}$ & $68.1 \mathrm{i}$ & & $12.5 \mathrm{~d}$ & $11.1 \mathrm{e}$ & $9.7 \mathrm{~g}$ & \\
\hline \multicolumn{2}{|c|}{ Mean (C) } & $456.1 \mathrm{~A}$ & 387.8B & $358.9 \mathrm{C}$ & & \multicolumn{2}{|c|}{\begin{tabular}{|l|l|}
$68.68 A$ & $67.14 B$ \\
\end{tabular}} & $52.85 \mathrm{C}$ & & $12.78 \mathrm{~A}$ & 10.59B & $8.79 \mathrm{C}$ & \\
\hline \multirow{2}{*}{\multicolumn{2}{|c|}{ Mean (B) }} & 50 & 100 & 150 & & 50 & 100 & 150 & & & 100 & 150 & \\
\hline & & $518.1 \mathrm{~A}$ & $361.0 B$ & $323.7 \mathrm{C}$ & & \multicolumn{3}{|c|}{\begin{tabular}{|l|l|l|}
$84.15 \mathrm{~A}$ & $57.08 \mathrm{~B}$ & $47.44 \mathrm{C}$ \\
\end{tabular}} & & \multicolumn{2}{|c|}{\begin{tabular}{|l|l|l|}
$12.87 \mathrm{~A}$ & $10.27 \mathrm{~B}$ \\
\end{tabular}} & 9.02 & \\
\hline \multicolumn{14}{|c|}{ Root $>2 \mathrm{~mm}$, } \\
\hline \multirow{3}{*}{$I_{1}$} & 50 & $220.0 c$ & $160.0 \mathrm{~h}$ & 133.01 & \multirow{3}{*}{$114.8 \mathrm{C}$} & $17.6 \mathrm{jk}$ & $14.3 \mathrm{mn}$ & $11.0 p$ & & $20.0 \mathrm{~d}$ & $11.8 \mathrm{~h}$ & $6.1 \mathrm{kl}$ & \\
\hline & 100 & $155.0 \mathrm{i}$ & $125.0 \mathrm{~m}$ & $90.0 p$ & & 16.01 & 13.00 & $10.0 \mathrm{q}$ & $13.09 \mathrm{C}$ & $10.6 \mathrm{hi}$ & $8.1 \mathrm{ij}$ & 5.01 & $9.02 \mathrm{C}$ \\
\hline & 150 & $60.0 \mathrm{t}$ & 70.0r & 20.0uv & & $14.7 \mathrm{mn}$ & $11.9 p$ & $9.2 q$ & & $8.9 \mathrm{ij}$ & $6.4 \mathrm{kl}$ & 4.3I & \\
\hline & 50 & $244.2 b$ & $177.6 f$ & 147.6j & & 23.1f & $19.8 \mathrm{i}$ & $16.5 \mathrm{k}$ & & $28.1 \mathrm{~b}$ & $14.8 f$ & 7.6j & \\
\hline $\mathrm{I}_{2}$ & 100 & $172.1 \mathrm{f}$ & $138.8 \mathrm{k}$ & 99.90 & 127.4B & $21.0 \mathrm{~h}$ & $18.0 \mathrm{j}$ & $15.0 \mathrm{~m}$ & 18.12B & $13.2 \mathrm{~g}$ & 10.1hi & $6.5 \mathrm{kl}$ & $11.62 \mathrm{~B}$ \\
\hline & 150 & $66.6 s$ & $77.7 q$ & $22.2 u$ & & $19.3 \mathrm{ij}$ & $16.6 \mathrm{k}$ & $13.8 \mathrm{mn}$ & & $11.1 \mathrm{~h}$ & $8.0 \mathrm{j}$ & 5.11 & \\
\hline & 50 & 293.0a & 213.1d & $177.2 \mathrm{e}$ & & $33.0 \mathrm{a}$ & 27.5d & $22.0 \mathrm{~g}$ & & $33.5 \mathrm{a}$ & $22.8 \mathrm{c}$ & $9.0 \mathrm{i}$ & \\
\hline$I_{3}$ & 100 & 206.5e & $166.5 \mathrm{~g}$ & $119.9 n$ & 152.9A & $30.0 \mathrm{~b}$ & $25.0 \mathrm{e}$ & $20.0 \mathrm{i}$ & $25.17 \mathrm{~A}$ & $15.9 \mathrm{e}$ & $12.7 \mathrm{~g}$ & $7.8 \mathrm{j}$ & $14.65 \mathrm{~A}$ \\
\hline & 150 & $79.9 q$ & 93.2op & $26.6 u$ & & $27.6 \mathrm{c}$ & 23.0f & $18.4 \mathrm{j}$ & & $13.9 \mathrm{fg}$ & $9.3 \mathrm{i}$ & $7.0 \mathrm{k}$ & \\
\hline Mea & In (C) & 166.4A & $135.8 \mathrm{~B}$ & $92.9 \mathrm{C}$ & & $22.48 \mathrm{~A}$ & 18.79B & $15.10 \mathrm{C}$ & & $17.24 \mathrm{~A}$ & 11.55B & 6.49C & \\
\hline & & 50 & 100 & 150 & & 50 & 100 & 150 & & 50 & 100 & 150 & \\
\hline & & 196.2A & $141.5 B$ & $57.4 \mathrm{C}$ & & $20.53 A$ & 18.67B & $|17.17 \mathrm{C}|$ & & $17.08 \mathrm{~A}$ & 9.98B & $8.23 \mathrm{C}$ & \\
\hline
\end{tabular}

\section{CONCLUSION}

From the found results in this study may be recommend that, apple growers can use raised bed technique ( $2 \mathrm{~m}$ wide) on clay loamy soil to save 1439.5 or $1452.1 \mathrm{~m}^{3} / \mathrm{fed}$./year, increase water use growth and supports roots to penetrate with higher percentages to longer distances and deeper depths. 
A.O.A.C. (1990). Association of Official Agricultural Chemists. Official Methods of Analysis. $12^{\text {th }}$ ed. Washington, D. C., USA.

Ali, M. A. and Y. N. Gobran (2002). Effect of soil moisture regimes and potassium application on growth, yield, fruit quality of Washington Navel orange trees. Annals of Agric Sc., Moshtoher, 40 (3): 1669-1697.

Ashraf, M. (2010). Inducing drought tolerance in plants: recent Advances, Biotechnol. Adv. 28. 169-183.

Bhuyan, M.H.M., M. R. Ferdousi, M.T. lqbal and A. K. Hasan (2016). Raised bed planting provides higher yield and less water inputs for transplanted boro rice (Oryza sativa) than conventional planting method. Journal of Advanced Studies in Agricultural, Biological and Environmental Sciences (JABE), 3 (1): 17-31.

Cahoon, G.A., E. S. Morton, W.W. Jones and M. J. Garber (1959). Effects of various types of nitrogen fertilizers on root density and distribution as related to water infiltration and fruit yields of Washington Navel oranges in a long-term fertilizer experiment. In Proc. Amer. Soc. Hort. Sci (Vol. 74, pp. 289-299).

Chapman, H.D. and F. Pratt (1961). "Methods of Analysis for Soils, Plants and Water". Univ. of Calif., 35 (5), 6-7.

Cottenie, A., M. Verlo, L. Kiekeus, G. Velghe and R. Camerlynck (1982). Chemical Analysis of Plants and Soils. Laboratory of Analytical and Agrochemistry State University, Ghent-Belgium.

Farré, I. and J.M. Faci (2006). Comparative response of maize (Zea mays L.) and sorghum (Sorghum bicolor L. Moench) to deficit irrigation in a Mediterranean environment. Agric. Water Manage. 83: 135-143.
Fathi, M. A. (1999a). Drip irrigation efficiency for pear trees. A: Yield, fruit properties and vegetative growth. J. Agric. Sci., Mansoura Univ., 24 (6): 3021-3034.

Fathi, M. A. (1999b). Drip irrigation efficiency for pear trees. B- Root system growth and distribution. J. Agric. Sci., Mansoura Univ., 24 (6): 3035-3049.

Ford, H.W. (1962). Thickness of sub soil organic layer in relation to tree size and root distribution of citrus. J. Amer. Soc. Hort. Sci., 82: 177-179.

Green, S. and B. Clothier (1999). The root zone dynamics of water uptake by a mature apple tree. Plant and Soil, 206(1), 61-77.

Hilgeman, R. H. and F. O. Sharo (1970). Response of irrigation on yield and quality of orange. Agric. Res. Rev. Cairo, 95: 739-49.

Hillel, D. (2004). Introduction to Environmental Soil Physics. New York: Elsevier Academic Press.

Hobbs, P.R., K.D. Sayre and J. I. OrtizMonasterio (1998). Increasing wheat yields sustainability through agronomic means. NRG Paper 98-01. Mexico, D.F. Mexico. 22 p.

Humphreys, E., S. Thaman, A. Prashar, P.R. Gajri, S.S. Dhillon, Y. Singh, A. Nayyar, J. Timsina and B. Singh (2004). Productivity, water use efficiency and hydrology of wheat on beds and flats in Punjab, India. CSIRO Land and Water Technical Report No. 3/04. Australian Center for International Agricultural Research, Australia, 2004.

Hussein, S. M. (1998). Influence of irrigation levels on the growth, mineral content and fruit quality of "Anna" apple. M. Sci. Thesis, Cairo Univ.

Hussein, S. M. M. and T. A. Eid. (2013). Response of plum trees grown in clay loamy soil to the change from surface 
to drip irrigation system. Agric. J. of Appl. Sci., 28 (5): 218-240.

Hussien, S.M., M. A. Fathi and T. A. Eid (2013). Effect of shifting to drip irrigation on some plum cultivars grown in clay loamy soil. Egypt. J. Agric. Res., 91 (1), 217-233.

Ibrahim, M.A. (1981). Evaluation of different methods for calculating potential evapotranspiration in north Delta region. Ph. D. thesis, Fac. Agri. Alex. Univ.

Israelsen, O.W. and V.E. Hansen (1962). Irrigation Principles and Practices John Willey and Son Inc. New York

Kabeel, H., S.M. Hussien, E.A. Ismail and T. A. Eid (2013). comparative study on the effect of change the surface irrigation to bubbler irrigation systems of fruitful "le-conte" pear trees. J. Soil Sci. and Agric. Eng., Mansoura Univ., Vol. 4 (4): 399 - 416.

Karrou, M., O. Theib, A. E. El Rashad and M. Sherif (2012). Yield and water productivity of maize and wheat under deficit and raised bed irrigation practices in Egypt. African Journal of Agricultural Research Vol. 7(11), pp. 1755-1760.

Klute, A. (1986). Methods of Soil Analysis. Part 1. 2nd ed. ASA and SSSA. Madison, Wisconsin, USA.

Magness, J.R. and G.F. Taylor (1925). An Improved Type of Pressure Tester for the Determination of Fruit maturity. U. S. Dept. Agric. CIRC., 3508p.

Michael, A.M. (1978). Irrigation theory and practice. Vikas Publishing House PVTLTD New Delhi, Bombay.

Moursi, E.A. and W.M.B. Yehia (2016). Towards effective irrigation management for cotton crop under different cultivation methods in the North Middle Nile delta region. J. Soil Sci. and Agric. Eng., Mansoura Univ., Vol. 7 (1): 21-34.
Murphy, J. and J. P. Reily (1962). A Modified Single Method for the Determination of Phosphorus in Natural Water. Anal. Chemi. Acta, 27:31-36.

Sayre, K.D. and P.R. Hobbs (2004). The raised bed system of cultivation for irrigated production conditions. In: Lal, R Hobbs, PR Uphoff, N, Hansen, DO (eds) Sustainable agriculture and the International Rice- Wheat System. New York, USA: Marcel Dekker.

Sokalska, D. I., D. Z. Haman, A. Szewczuk and D. Deren (2009). Spatial root distribution of mature apple trees under drip irrigation system. Agricultural Water Management, 96(6), 917-924.

Stackman, W.P. (1966). Determination of pore size by the air bubbling pressure method. Proceeding UnesceSymp on Water in The Unsaturated Zone, 366372.

Swelam, A. and Y. Atta (2011). New approach of farm management under surface irrigation to improve water saving and productivity. New Horizons in Sci. Technol. 1:76-83.

Tanner, C. B. and T. R. Sinclair (1983). Efficient water use in crop production. In H. M. Taylor, W. R. Jordan, \& T. R. Sinclair (Eds.), Limitations to efficient water use in crop production (pp.127). Madison.

Thompson, T.L., H.C. Pang and Y. Y. Li (2009). The potential contribution of subsurface drip irrigation to watersaving agriculture in the Western USA, Agr. Sci. China 8. 850-854.

Vites, F.G. (1965). Increasing Water use Efficiency by Soil Management. Amer. Soc. Agron, Madison.

Vogel, A. (1968). A Text Book of Quantitative Inorganic Analysis, Longmans, New York, pp. 1216. Wisc. pp. 259-274. 
M. A. Fathi, et al.,

Waller, R. A. and D. B. Duncan (1969). A basic rule for the symmetric multiple comparison

Amer.Statis.Assoc.J.12:1485-1503.

Westwood, M. N. (1978). Temperate Zone

Pomology W. H. Freeman and

Company. San Francisco.

دراسة مقارنة عن تأثير طرق الري بالغمر المختلفة ونقص الرطوية على أشجار التفاح
Zayan, M.A. and E. Morsy (1989). Studied on rest period of "Anna" apple buds under the agroclimatic conditions in North Delta. J. Agric. Res. Tanta Univ., 15(1): 54-64.

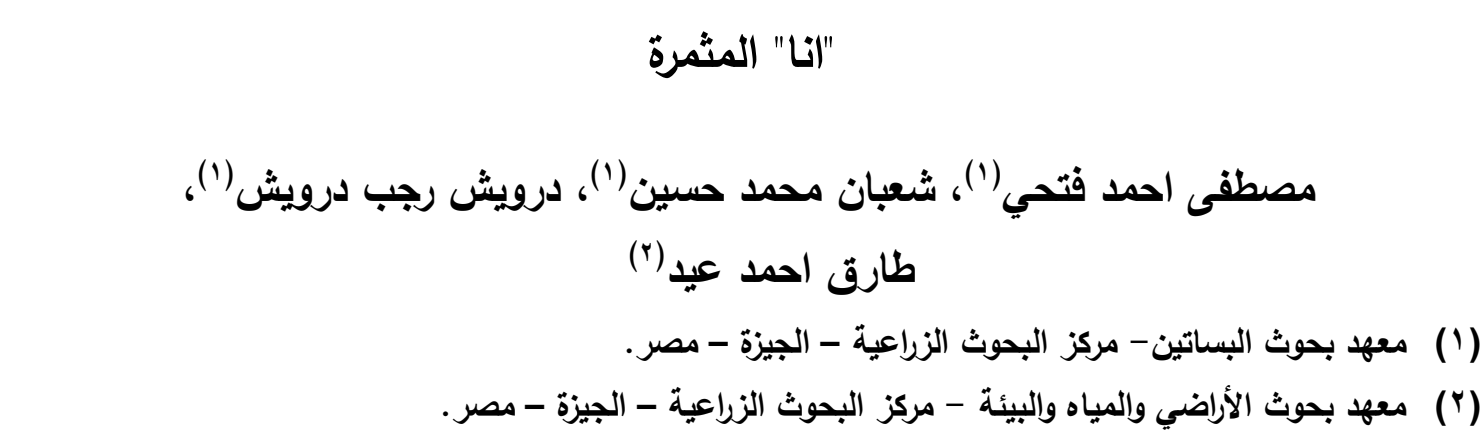

الملخص العربي

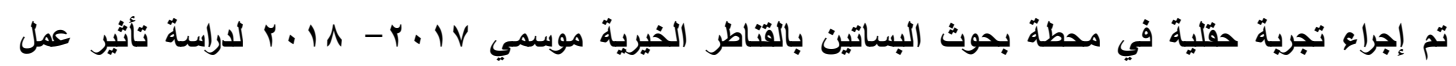

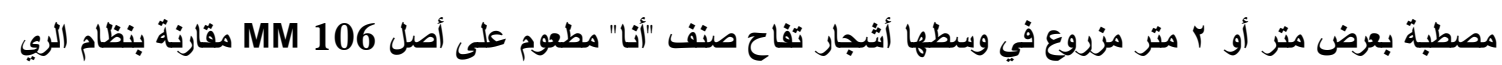

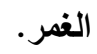

أوضحت النتائج أن عمل مصطبة بعرض r متر ( امتر من كلا جانبي الثجرة) مع عمل قناة ري بين كل مصطبة

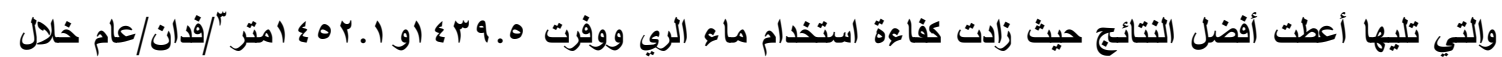
عامي الاراسة.

بالإضافة الى ذلك فإن عمل مصطبة بعرض كمتر أدت الى زيادة كل من النمو الخضري وعقد الثمار والمحصول زيادة

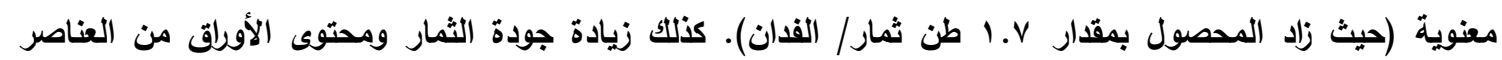

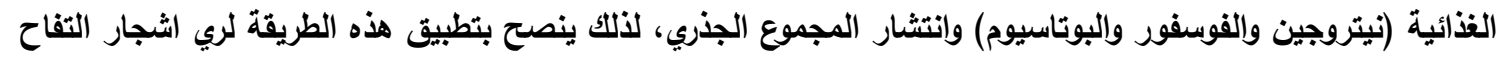
في الأراضي الطينية بل الري السطدي. 
السادة المحكمين

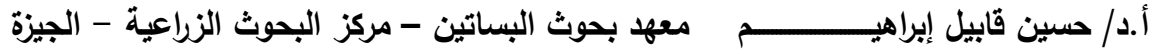

$$
\begin{aligned}
& \text { أ.د/ الحسينى عبدالغفار أبو حسين كلية الزراعة - جامعة المنوفية }
\end{aligned}
$$

